\title{
Clinicopathological features and post-resection outcomes of hepatocellular adenoma
}

\author{
Sung-Min Kim ${ }^{1}$, Shin Hwang ${ }^{1}$, Chul-Soo Ahn ${ }^{1}$, Ki-Hun Kim¹, Deok-Bog Moon ${ }^{1}$, Tae-Yong Ha ${ }^{1}$, \\ Gi-Won Song ${ }^{1}$, Dong-Hwan Jung ${ }^{1}$, Gil-Chun Park ${ }^{1}$, and Seung-Mo Hong ${ }^{2}$ \\ Departments of ${ }^{1}$ Surgery and ${ }^{2}$ Pathology, Asan Medical Center, \\ University of Ulsan College of Medicine, Seoul, Korea
}

\begin{abstract}
Backgrounds/Aims: Hepatocellular adenomas (HCA) are rare benign liver tumors with the potential of malignant transformation and risk of bleeding. We investigated the clinicopathological features and outcomes of HCA in 19 patients who underwent surgical resection. Methods: This retrospective observational study included 19 patients who underwent hepatic resection during a 9-year period from 2011 to 2019. Results: The incidence of HCA was $0.18 \%$ of all hepatic resection cases during the study period. The mean age of the patients was $34.3 \pm 9.6$ years, and 12 patients $(63.2 \%)$ were female. Abdominal pain was present as initial clinical manifestation in 5 patients and the other 14 patients had no specific symptoms. HCA was diagnosed in 7 out of 8 patients who underwent liver biopsy. R0 resection was performed in 18 patients (94.7\%) and laparoscopic liver resection was performed in 11 patients (57.9\%). The mean tumor size was $5.6 \pm 3.6 \mathrm{~cm}$ and 17 patients had a single tumor. Immunohistochemical analysis of the resected tumor specimens revealed hepatocyte-nuclear-factor- $1 \alpha$ mutated HCA in $2(10.5 \%), \beta$-catenin-mutated HCA in $2(10.5 \%)$, inflammatory HCA in $12(63.2 \%)$ and unclassified HCA in $3(15.8 \%)$. There were no pathognomonic findings in the preoperative liver imaging studies among these four groups. Currently, all patients are alive with a mean follow-up period of $40.1 \pm 26.3$ months. One patient showed residual tumors after incomplete resection. Conclusions: Surgical resection may be indicated if imaging studies show diagnostic ambiguity, growing tumor or symptomatic mass. Because of the risk of tumor recurrence and malignant transformation, long-term follow-up is necessary. (Ann Hepatobiliary Pancreat Surg 2021;25:25-33)
\end{abstract}

Key Words: Malignant potential; Focal nodular hyperplasia; Bleeding; Resection; Abdominal pain

\section{INTRODUCTION}

Hepatocellular adenomas (HCA) are rare benign liver tumors with the potential of malignant transformation and risk of bleeding. Epidemiologic studies report the prevalence of HCA as approximately 3-4 cases per 100,000 people in Europe and North America, ${ }^{1}$ and lower prevalence in Asian countries. ${ }^{2}$ The highest prevalence has been described in females taking oral contraceptives, but other risk factors, such as anabolic steroid use, obesity and metabolic syndrome have also been defined. ${ }^{2,3}$

In 2006, four subtypes of HCA have been proposed, which were based on genotype-phenotype analyses. ${ }^{4}$ Of them, the $\beta$-catenin-mutated subtype is known to be asso- ciated with an increased risk of malignant transformation into hepatocellular carcinoma (HCC) ${ }^{5-8}$ Approximately 9\% of HCA may transform into HCC with risk factors including male sex, androgen use, large tumors $(>5 \mathrm{~cm})$ and $\beta$-catenin-mutated HCA. ${ }^{9}$

The diagnostic workup of HCA is mainly based on cross-sectional imaging studies, of which magnetic resonance imaging (MRI) and computed tomography (CT) are commonly used to assess this lesion. The most sensitive method to differentiate HCA from other similar intrahepatic mass is MRI with hepatobiliary contrast. ${ }^{10-12}$ If the findings of imaging studies are inconclusive, a percutaneous liver biopsy may be necessary for the final diagnosis. $^{13}$

Received: September 24, 2020; Revised: September 29, 2020; Accepted: October 1, 2020

Corresponding author: Shin Hwang

Department of Surgery, Asan Medical Center, University of Ulsan College of Medicine, 88 Olympic-ro 43-gil, Songpa-gu, Seoul 05505, Korea Tel: +82-2-3010-3930, Fax: +82-2-3010-6701, E-mail: shwang@amc.seoul.kr

Copyright (C) 2021 by The Korean Association of Hepato-Biliary-Pancreatic Surgery

This is an Open Access article distributed under the terms of the Creative Commons Attribution Non-Commercial License (http://creativecommons.org/ censes/by-nc/4.0) which permits unrestricted non-commercial use, distribution, and reproduction in any medium, provided the original work is properly cited. Annals of Hepato-Biliary-Pancreatic Surgery - pISSN: 2508-5778 - elSSN: 2508-5859 
In the present study, the clinicopathological features and outcomes of HCA in 19 patients who underwent surgical resection were investigated.

\section{MATERIALS AND METHODS}

\section{Patients}

The primary liver cancer database at our institution was extensively searched to identify patients diagnosed with HCA following hepatic resection. We identified 19 patients over a 9-year period from January 2011 to December 2019. During this study period, 10,753 cases of hepatic resection were performed for patients with various diseases in our institution; these 19 cases of HCA comprised approximately $0.18 \%$ of all the hepatic resection cases.

The medical records of the patients were retrospectively reviewed following the approval of the Institutional Review Board at our institution (IRB No. 2019-1347), which waived the requirement for informed consent due to the retrospective nature of the study. This study was performed in accordance with the ethical guidelines of the World Medical Association Declaration of Helsinki 2013. The patients were followed up until August 2020 by medical record review and with the assistance of the National Health Insurance Service.

\section{Preoperative evaluation, surgical procedures, and postoperative follow-up}

Routine preoperative evaluation for primary liver tumors has been described elsewhere. ${ }^{14}$ In general, the hepatic resection patients with borderline malignancy were followed up every 3-4 months during the first year after surgery and every 3-6 months thereafter. The general principles for the treatment of recurrent liver tumors were applied to our patients. ${ }^{14,15}$

\section{Pathological diagnosis}

Four subtypes of HCAs are recognized based on genotype-phenotype analyses: hepatocyte-nuclear-factor-1 $\alpha \mathrm{mu}-$ tated (H-HCA), $\beta$-catenin-mutated type with upregulation of glutamine synthetase (b-HCA), inflammatory type with serum-amyloid-A overexpression (I-HCA), and unclassified type (u-HCA). ${ }^{16}$ Inactivating mutations in the HNF1A (TCF1) gene lead to loss of hepatocyte nuclear factor $1 \alpha$ (HNF-1 $\alpha$ ) expression define H-HCA, which are charac- terized histologically by marked steatosis and bland hepatocyte cytology. Activating mutations of $\beta$-catenin (b-HCA) are associated with an increased risk of malignant transformation into HCC. Histologically, I-HCA is marked by inflammatory infiltrates or telangiectatic features with increased expression of serum amyloid A and C-reactive protein (CRP). A small proportion of HCA does not appear to fall into any of the above categories and was considered unclassifiable by current testing approaches (u-HCA).

The immunohistochemical analysis includes staining with serum amyloid A, liver fatty acid-binding protein, glutamine synthetase, $\beta$-catenin, Ki-67, cytokeratin 19, CD34, CRP and reticulin. Liver fatty acid-binding protein-negative cases were classified as H-HCA. HCA with strong and diffuse glutamine synthetase staining and/or $\beta$-catenin nuclear staining, regardless of the serum amyloid A staining status, was categorized as b-HCA. The remaining HCA with serum amyloid A positivity was classified as I-HCA.

\section{Statistical analysis}

Numeric data are presented as means and standard deviation or as median and range. As there were no cases of tumor recurrence, survival analysis was not performed. Statistical analyses were performed using SPSS version 22 (IBM, New York, NY).

\section{RESULTS}

\section{Patient demographics and preoperative diagnosis}

The clinicopathological features of the 19 patients with HCA are presented in Table 1. The mean age of the patients was $34.3 \pm 9.6$ years (range: 17-56 years), and 12 patients $(63.2 \%)$ were female. Hepatitis B virus (HBV) infection was present in one patient, and none of the patients had hepatitis $\mathrm{C}$ virus infection or non-viral liver cirrhosis. Abdominal pain was present as an initial clinical manifestation in 5 patients. The other 14 patients had no specific symptoms and the liver mass was detected incidentally on routine health screening or surveillance for other diseases.

In 8 patients who were suspected with HCA, percutaneous liver biopsy showed HCA-compatible pathological findings in 7 patients and no mass was identified in 1 
Table 1. The clinicopathological features of the 19 patients with hepatocellular adenoma

\begin{tabular}{|c|c|c|c|c|c|c|c|c|c|c|c|c|c|c|c|}
\hline Case No. & Sex & $\begin{array}{l}\text { Age } \\
\text { (yrs) }\end{array}$ & $\begin{array}{l}\text { Initial } \\
\text { findings }\end{array}$ & $\begin{array}{l}\text { Clinical } \\
\text { diagno- } \\
\text { sis }\end{array}$ & $\begin{array}{l}\text { Liver } \\
\text { biopsy }\end{array}$ & $\begin{array}{l}\text { AFP } \\
\text { (ng/ } \\
\text { ml) }\end{array}$ & $\begin{array}{c}\text { PIVK } \\
\text { A-II } \\
(\mathrm{mAu} / \\
\mathrm{ml})\end{array}$ & $\begin{array}{l}\text { CA19-9 } \\
(\mathrm{ng} / \mathrm{ml})\end{array}$ & $\begin{array}{l}\text { Extent } \\
\text { of } \\
\text { resec- } \\
\text { tion }\end{array}$ & $\begin{array}{l}\text { Type of } \\
\text { operation }\end{array}$ & $\begin{array}{l}\text { Tumor } \\
\text { size } \\
(\mathrm{cm})\end{array}$ & $\begin{array}{l}\text { Tu- } \\
\text { mor } \\
\text { No. }\end{array}$ & $\begin{array}{l}\text { Follow- } \\
\text { up } \\
\text { dura- } \\
\text { tion } \\
\text { (mos) }\end{array}$ & $\begin{array}{l}\text { Sur- } \\
\text { vival } \\
\text { status }\end{array}$ & $\begin{array}{c}\text { Tumor } \\
\text { re- } \\
\text { currence }\end{array}$ \\
\hline H-HCA_1 & $\mathrm{F}$ & 43 & $\begin{array}{l}\text { Abdominal } \\
\text { pain, SPK }\end{array}$ & $\begin{array}{l}\mathrm{HCC}, \\
\mathrm{HCA}\end{array}$ & No mass & 1.7 & 42 & 25.4 & LMS & Open & 3 & 1 & 13 & Alive & No \\
\hline H-HCA_2 & $\mathrm{F}$ & 40 & $\begin{array}{l}\text { Health } \\
\text { screening }\end{array}$ & HCA & HCA & 2.7 & 27 & 14 & LH & $\begin{array}{l}\text { Laparo- } \\
\text { scopy }\end{array}$ & 2.9 & 1 & 14 & Alive & No \\
\hline B-HCA_1 & $\mathrm{F}$ & 25 & $\begin{array}{l}\text { Abdominal } \\
\text { pain }\end{array}$ & $\begin{array}{l}\text { FNH, } \\
\text { HCA }\end{array}$ & & 3.5 & 155 & & RH & $\begin{array}{l}\text { Laparo- } \\
\text { scopy }\end{array}$ & 7.6 & 1 & 42 & Alive & No \\
\hline B-HCA_2 & $\mathrm{F}$ & 36 & $\begin{array}{l}\text { Health } \\
\text { screening }\end{array}$ & $\mathrm{HCA}$ & & 3.5 & 207 & 26.9 & LMS & $\begin{array}{l}\text { Laparo- } \\
\text { scopy }\end{array}$ & 6.9 & 1 & 55 & Alive & No \\
\hline I-HCA_1 & M & 34 & $\begin{array}{l}\text { FNH growth } \\
\text { for } 4 \text { years }\end{array}$ & FNH & & 4.1 & 37 & 8.5 & LLS & Open & 14.5 & 1 & 38 & Alive & No \\
\hline I-HCA_2 & M & 24 & $\begin{array}{l}\text { Health } \\
\text { screening }\end{array}$ & $\begin{array}{r}\mathrm{HCC}, \\
\mathrm{HCA}\end{array}$ & & 2.6 & 32 & 15.2 & S56 & Open & 9.7 & 1 & 50 & Alive & No \\
\hline I-HCA_3 & $\mathrm{F}$ & 34 & Fatigue & $\mathrm{HCA}$ & & 4.5 & 25 & 47.2 & LLS & Open & 8.5 & 1 & 15 & Alive & No \\
\hline I-HCA_4 & M & 32 & $\begin{array}{l}\text { Follow-up after } \\
\text { acute HAV }\end{array}$ & HCC & & 3 & 32 & 3.5 & LH & Open & 6.5 & 1 & 111 & Alive & No \\
\hline I-HCA_5 & M & 32 & $\begin{array}{l}\text { Liver } \\
\text { cirrhosis } \\
\text { screening }\end{array}$ & HCA & $\mathrm{HCA}$ & 2.5 & & & LLS & Open & 6.1 & 1 & 51 & Alive & No \\
\hline I-HCA_6 & $\mathrm{F}$ & 30 & $\begin{array}{l}\text { Health } \\
\text { screening }\end{array}$ & HCA & HCA & 4.6 & 29 & 13 & $\mathrm{RH}$ & $\begin{array}{l}\text { Laparo- } \\
\text { scopy }\end{array}$ & 4 & 1 & 12 & Alive & No \\
\hline I-HCA_7 & $\mathrm{F}$ & 47 & $\begin{array}{l}\text { HBV } \\
\text { screening }\end{array}$ & $\mathrm{HCC}$ & & 2.7 & 28 & 24.1 & LH & $\begin{array}{c}\text { Laparo- } \\
\text { scopy }\end{array}$ & 2.8 & 1 & 25 & Alive & No \\
\hline I-HCA_8 & $\mathrm{F}$ & 32 & $\begin{array}{l}\text { Liver } \\
\text { cirrhosis } \\
\text { screening }\end{array}$ & HCA & $\mathrm{HCA}$ & 1 & 27 & 18.8 & LH & $\begin{array}{c}\text { Laparo- } \\
\text { scopy }\end{array}$ & 2.8 & 6 & 23 & Alive & No \\
\hline I-HCA_9 & M & 42 & $\begin{array}{l}\text { Health } \\
\text { screening }\end{array}$ & $\mathrm{HCC}$ & & 1.8 & 22 & 6.5 & RPS & $\begin{array}{l}\text { Laparo- } \\
\text { scopy }\end{array}$ & 2.6 & 1 & 20 & Alive & No \\
\hline I-HCA_10 & F & 56 & $\begin{array}{l}\text { Health } \\
\text { screening }\end{array}$ & HCA & HCA & 2.4 & 15 & & RAS & $\begin{array}{l}\text { Laparo- } \\
\text { scopy }\end{array}$ & 2.3 & 1 & 52 & Alive & No \\
\hline I-HCA_11 & F & 27 & $\begin{array}{l}\text { Health } \\
\text { screening }\end{array}$ & HCA & HCA & 2.2 & 18 & & LLS & $\begin{array}{l}\text { Laparo- } \\
\text { scopy }\end{array}$ & 2 & 10 & 87 & Alive & $\begin{array}{l}\text { Yes- }> \\
\text { TACE }\end{array}$ \\
\hline I-HCA_12 & M & 40 & $\begin{array}{l}\text { Gallstone } \\
\text { work-up }\end{array}$ & $\begin{array}{l}\text { HCC, } \\
\text { AML }\end{array}$ & & 2.7 & 28 & 2 & $\mathrm{~S} 1$ & Open & 2 & 1 & 30 & Alive & No \\
\hline u-HCA_1 & F & 20 & $\begin{array}{l}\text { Abdominal } \\
\text { pain }\end{array}$ & $\begin{array}{l}\mathrm{HCC} \\
\mathrm{HCA}\end{array}$ & & 1.1 & 58 & 6.5 & RH & Open & 11.6 & 1 & 62 & Alive & No \\
\hline u-HCA_2 & M & 41 & $\begin{array}{l}\text { FNH growth } \\
\text { for } 2 \text { years }\end{array}$ & $\begin{array}{l}\text { HCA, } \\
\text { FNH }\end{array}$ & & 2.4 & 24 & & RAS & $\begin{array}{l}\text { Laparo- } \\
\text { scopy }\end{array}$ & 6.5 & 1 & 23 & Alive & No \\
\hline u-HCA_3 & $\mathrm{F}$ & 17 & $\begin{array}{l}\text { Abdominal } \\
\text { pain }\end{array}$ & HCA & HCA & 1 & 23 & & LMS & $\begin{array}{l}\text { Laparo- } \\
\text { scopy }\end{array}$ & 4.5 & 1 & 38 & Alive & No \\
\hline
\end{tabular}

AFP, alpha-fetoprotein; PIVKA-II, protein induced by Vitamin K absence or antagonist-II; CA19-9, carbohydrate antigen 19-9; M, male; F, female; HCA, hepatocellular adenoma; H-HCA, hepatocyte-nuclear-factor-1 $\alpha$ mutated HCA; b-HCA, $\beta$-catenin-mutated HCA; I-HCA, inflammatory HCA; u-HCA, unclassified HCA; HCC, hepatocellular carcinoma; FNH, focal nodular hyperplasia; AML, angiomyolipoma; RH, right hepatectomy; LH, left hepatectomy; RAS, right anterior sectionectomy; RPS, right posterior sectionectomy; LMS, left medial sectionectomy; LLS, left lateral sectionectomy; S56, resection of segment V and VI; S1, isolated caudate lobectomy; TACE, transarterial chemoembolization; SPK, simultaneous pancreas-kidney transplantation

patient. The preoperative clinical diagnoses in 12 patients who were not pathologically diagnosed with HCA were HCC in 3 patients, HCC or HCA in 3 patients, HCA in 2 patients, focal nodular hyperplasia (FNH) in 2 patients, FNH in 1 patient, and HCC or angiomyolipoma in 1 patient.
Two patients showed progressive growth of the liver tumor over 2 and 4 years, respectively under the clinical diagnosis of FNH. One patient underwent simultaneous pancreas-kidney transplantation 6 years before and liver mass was detected owing to abdominal pain. One patient 
had a history of oral contraceptive administration for 10 years.

The mean and median levels of alpha-fetoprotein (AFP; reference: $7.5 \mathrm{ng} / \mathrm{ml}$ ) were $2.6 \pm 1.1 \mathrm{ng} / \mathrm{ml}$ and $2.6 \mathrm{ng} / \mathrm{ml}$, those of protein induced by Vitamin $\mathrm{K}$ absence or antagonist-II (PIVKA-II; reference: $40 \mathrm{mAU} / \mathrm{ml}$ ) were $46.1 \pm 50.8$ $\mathrm{mAU} / \mathrm{ml}$ and $28 \mathrm{mAU} / \mathrm{ml}$, and those of carbohydrate antigen 19-9 (CA19-9; reference: $37 \mathrm{ng} / \mathrm{ml}$ ) were $16.3 \pm 12.4$

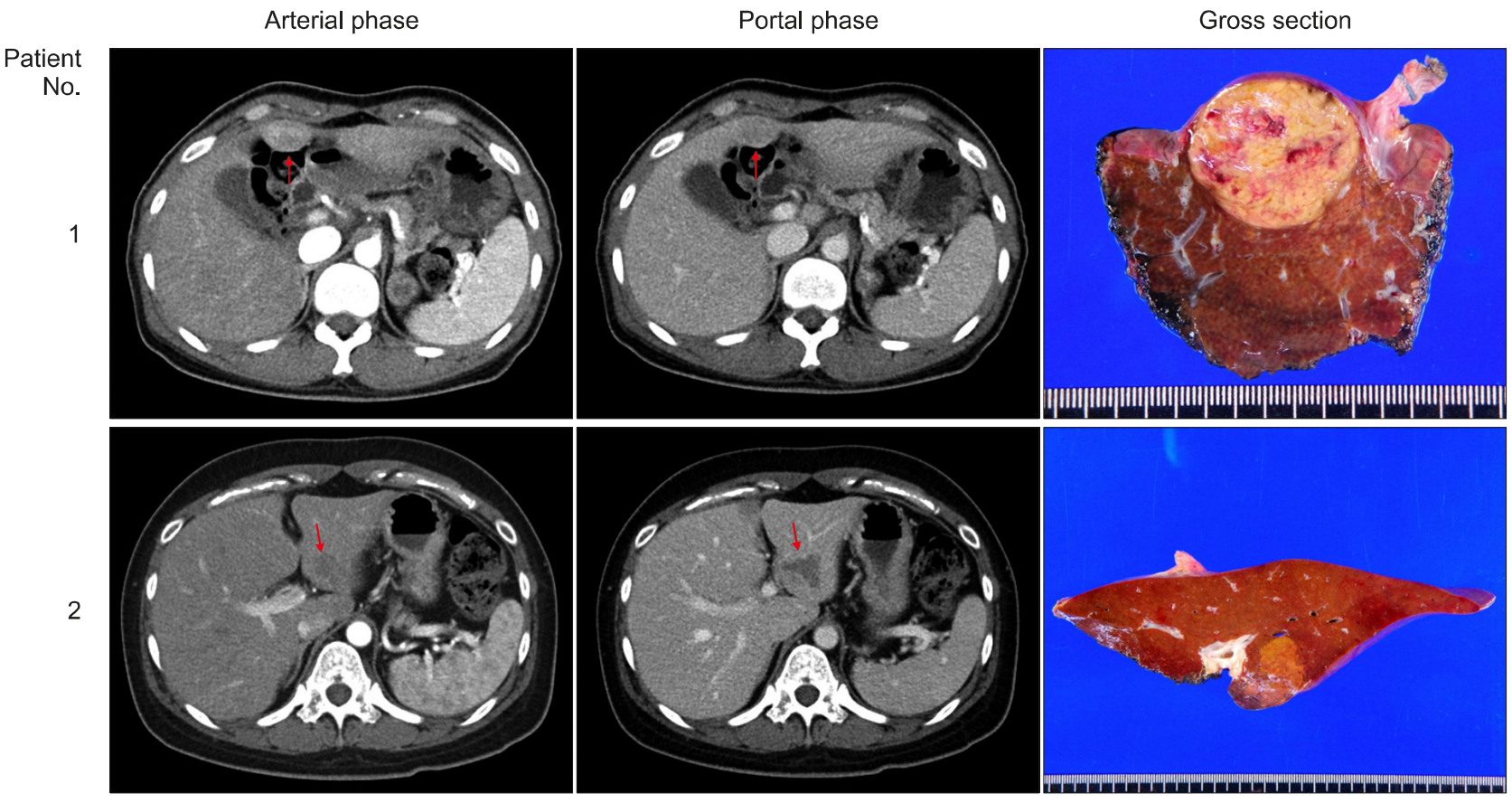

Fig. 1. Preoperative computed tomography findings and gross photographs of the surgical specimens of two patients with hepatocyte-nuclear-factor-1 $\alpha$ mutated hepatocellular adenoma. Numbers denote case numbers. Arrows indicate hepatocellular adenoma.

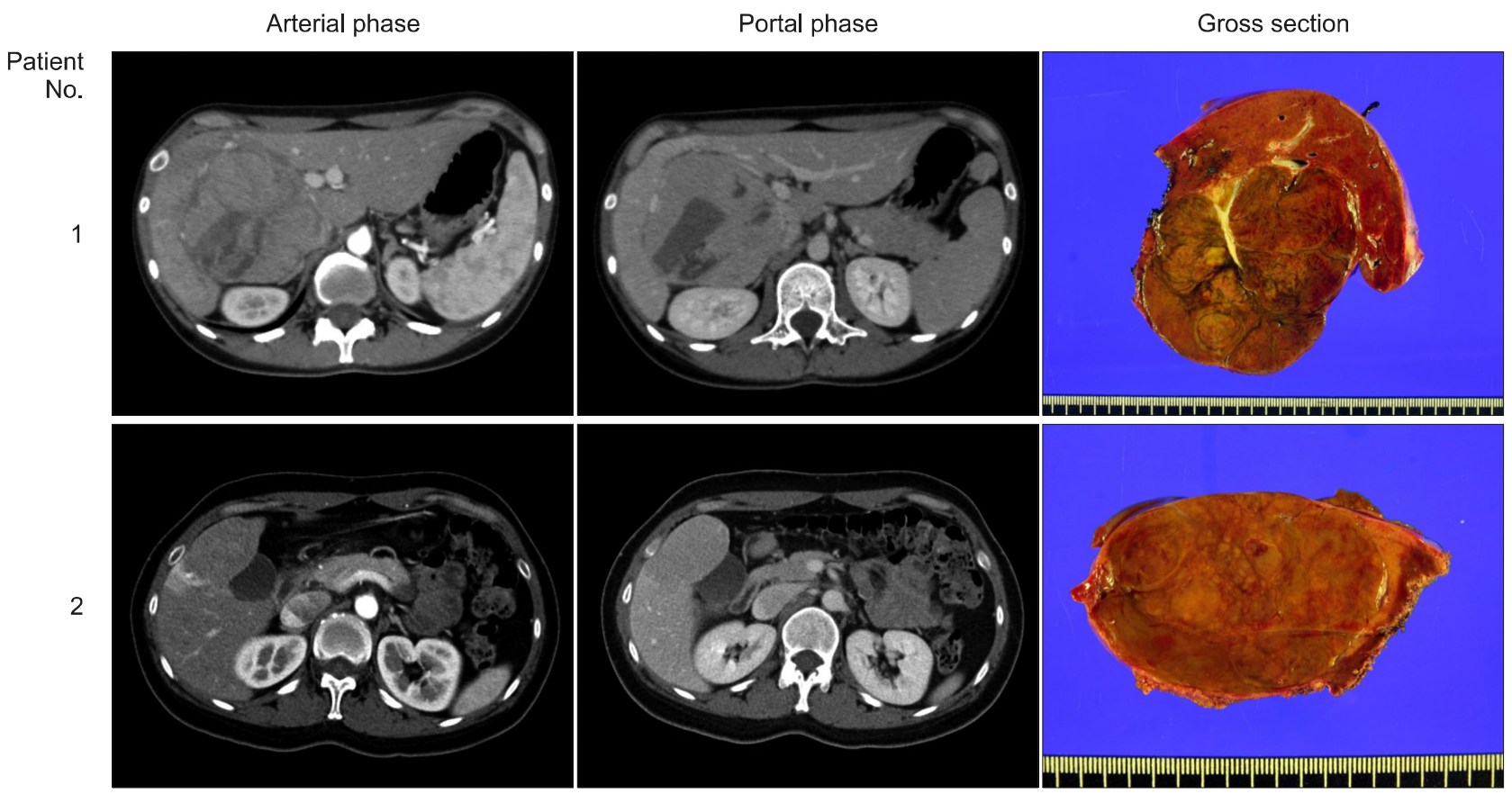

Fig. 2. Preoperative computed tomography findings and gross photographs of the surgical specimens of two patients with $\beta$-catenin-mutated hepatocellular adenoma. Numbers denote case numbers. 
$\mathrm{ng} / \mathrm{ml}$ and $14.0 \mathrm{ng} / \mathrm{ml}$, respectively. Only 5 patients showed an elevated level of either PIVKA-II or CA19-9.

\section{Outcomes after hepatic resection}

One patient underwent preoperative portal vein embolization for right hepatectomy. The extent of hepatic resection comprised of right hepatectomy $(n=4)$, left hepatectomy $(\mathrm{n}=4)$, right anterior sectionectomy $(\mathrm{n}=2)$, right posterior sectionectomy $(\mathrm{n}=1)$, left medial sectionectomy $(\mathrm{n}=3)$, left lateral sectionectomy $(\mathrm{n}=4)$, segment $\mathrm{V}$ and VI resection $(n=1)$, and isolated caudate lobectomy $(n=1)$. Laparoscopic liver resection was performed in 11 patients (57.9\%). All operations except one (I-HCA Case No. 11) were macroscopic curative resection with tumor-negative resection margins. None of the patients experienced surgical complications that required any intervention or surgical treatment.

The mean and median tumor sizes were $5.6 \pm 3.6 \mathrm{~cm}$ and
$4.5 \mathrm{~cm}$, respectively. Each one patient had 6 and $10 \mathrm{tu}-$ mors, and the other 17 patients had a single tumor. The location of the tumor was the right liver in 8 patients, the left liver in 10 patients, and the caudate lobe in 1 patient.

Immunohistochemical analysis of the resected tumor specimens revealed H-HCA in 2 patients (10.5\%, Fig. 1), b-HCA in 2 patients (10.5\%, Fig. 2), I-HCA in 12 patients (63.2\%, Fig. 3) and u-HCA in 3 patients (15.8\%, Fig. 4). There were no pathognomonic findings in the preoperative liver CT scans among these four groups.

Currently, all patients are alive over a mean follow-up period of 40.1 \pm 26.3 months (range, 12-111 months). Only one patient (I-HCA Case No. 11) who had undergone incomplete tumor removal showed slow growth of the residual tumors, thus this patient underwent transarterial chemoembolization (TACE) at 7 months after hepatic resection (Fig. 5). The largest $2 \mathrm{~cm}$-sized tumor was regressed after TACE, but other new small masses were re-

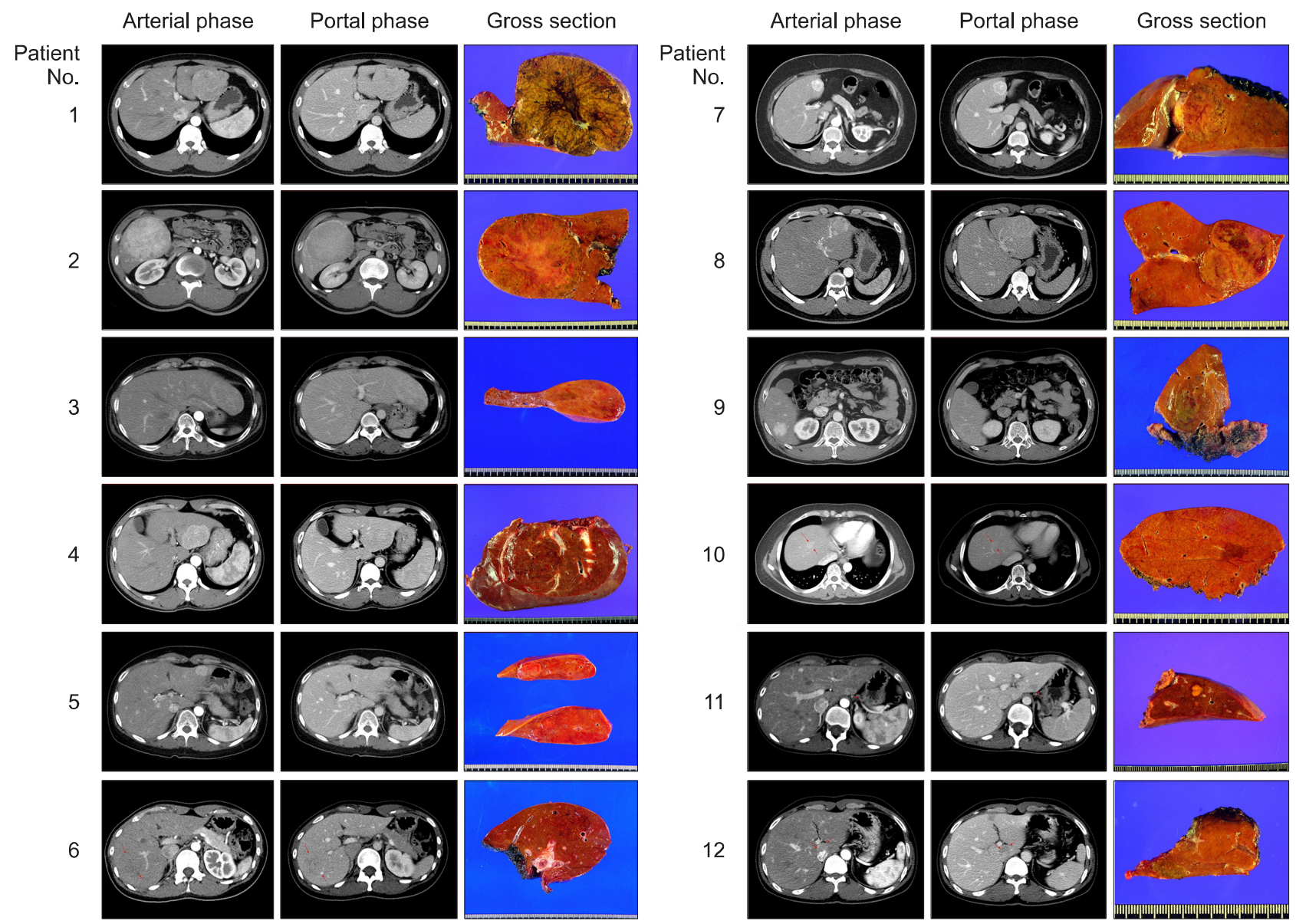

Fig. 3. Preoperative computed tomography findings and gross photographs of the surgical specimens of 12 patients with inflammatory hepatocellular adenoma. Numbers denote case numbers. Arrows indicate hepatocellular adenoma. 

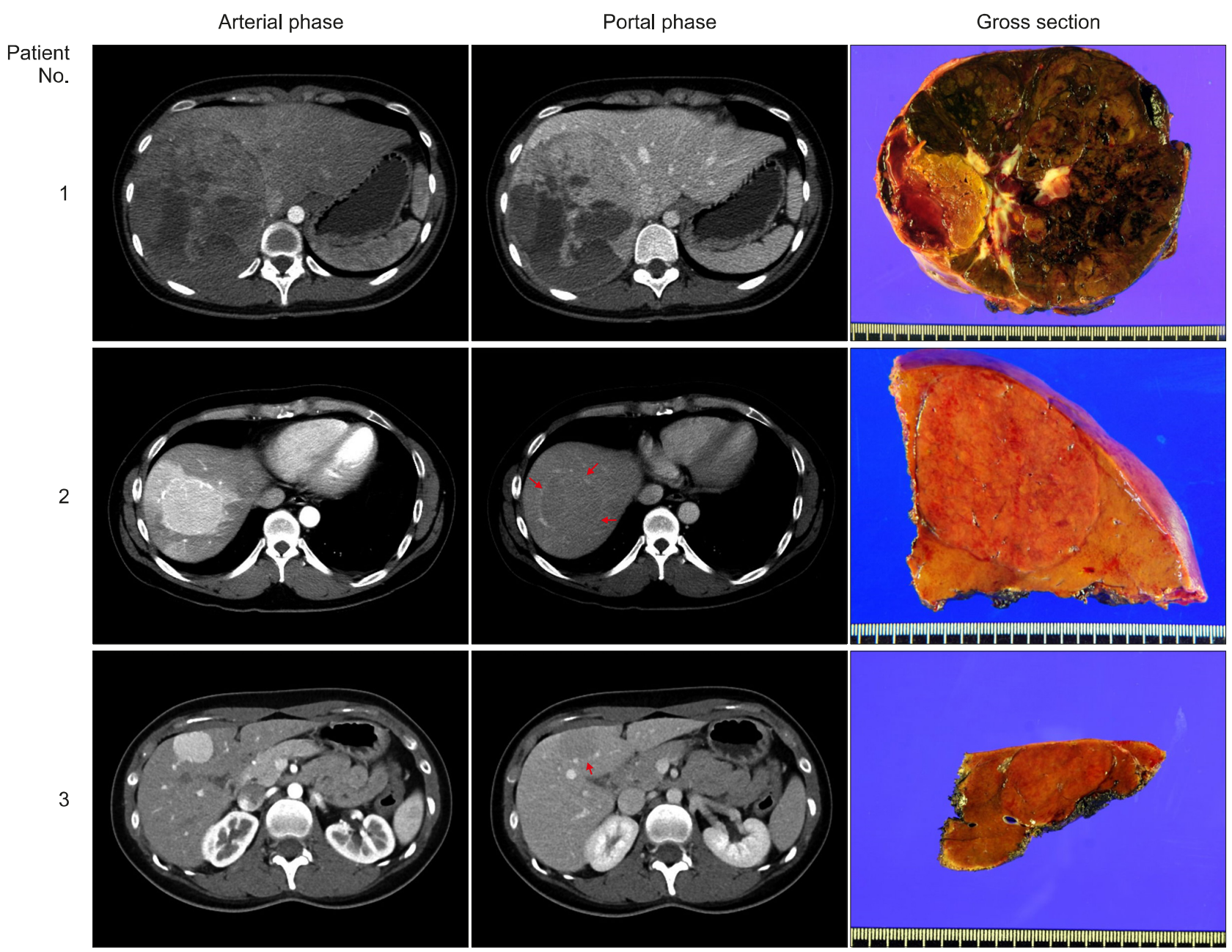

Fig. 4. Preoperative computed tomography findings and gross photographs of the surgical specimens of three patients with unclassified hepatocellular adenoma. Numbers denote case numbers. Arrows indicate hepatocellular adenoma.

maining; thus, this patient has been closely observed under imaging study follow-up every 6 months with consideration of liver transplantation. The other 18 patients did not show disease recurrence during follow-up to date.

\section{DISCUSSION}

Diagnostic workup for HCA should include hepatobiliary contrast MRI because it is helpful for discrimination from $\mathrm{FNH}^{17}$ In most of the cases, the diagnoses can be differentiated based on signal intensity and dynamic vascular patterns after intravenous gadolinium injection MRI. ${ }^{18}$ Under the condition of uncertainty, a biopsy should be taken, especially for larger lesions, as the clinical management will differ depending on the pathology. Although HCA is a hypervascular tumor with a risk of procedure-associated bleeding, percutaneous needle liver biopsy was performed in 8 of 19 patients in this study, and 7 of 8 patients were pathologically diagnosed with HCA.

Hepatic resection has been considered as the treatment of choice because complete surgical removal of HCA can be achieved. Elective surgical resection is considered for $\mathrm{HCA}>5 \mathrm{~cm}$ in diameter. Hepatic resection for HCA is a safe procedure with acceptably low morbidity and mortality rates. ${ }^{17,19}$ There was no major surgical complication in our 19 patients.

In this study, 11 of 19 patients underwent laparoscopic resection primarily because of the high proportion of young female patients and the benign nature of HCA. Laparoscopic resection is increasingly popular worldwide. de'Angelis et al. ${ }^{20}$ reported about $62 \mathrm{HCA}$ patients who underwent either an open procedure or laparoscopy, in which there was no difference in postoperative morbidity and zero mortality, with no long-term complications or re- 

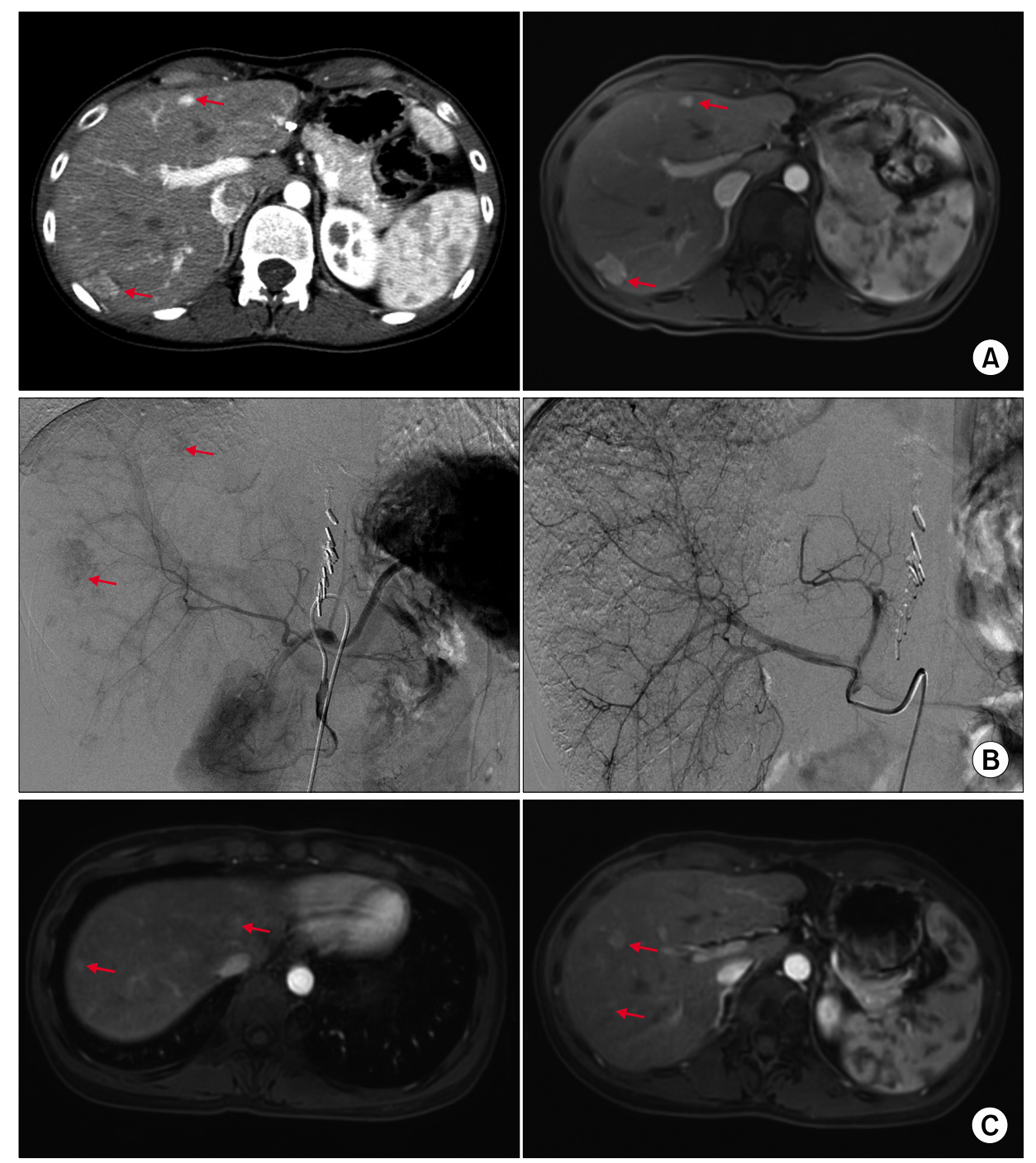

Fig. 5. Postoperative sequences of residual tumors in the inflammatory hepatocellular adenoma (Case No. 11). (A) At 5 months after hepatic resection, the slow progression of multiple residual tumors can be seen. (B) Transarterial chemoembolization was performed at 7 months after hepatic resection. (C) Magnetic resonance imaging taken at 7 years after hepatic resection shows no changes in the multiple tumors. Arrows indicate hepatocellular adenomas.

currence of HCA. Patients with smaller lesions were preferentially treated with laparoscopic approach.

In rare circumstances, the treatment of HCA may also involve liver transplantation, a procedure described in a case report by Vennarecci et al. ${ }^{21}$ Our patient with multiple recurrences was diagnosed with hepatic adenomatosis, and is under consideration of liver transplantation.

Few treatment options other than surgical resection have been proposed. Percutaneous radiofrequency ablation has been performed for HCA with good results. ${ }^{22}$ For HCAs $<3 \mathrm{~cm}$, radiofrequency ablation can be a good treatment option depending on the location of the lesion.

As HCAs are hypervascular arterial lesions, bleeding may be treated by transarterial embolization (TAE) in cases where patients present with hemodynamic instability. The embolization of HCAs is a safe but relatively chal- lenging procedure due to multiple small feeding vessels. ${ }^{23}$ In cases of spontaneous rupture and bleeding, TAE should be considered as a first-line treatment as it is highly successful and minimally invasive in an acute setting. Although high success rates have been described for TAE, there exists limited data in the literature. ${ }^{24}$

Four subtypes of HCAs are recognized based on genotype-phenotype analyses as H-HCA, b-HCA, I-HCA, and u-HCA. ${ }^{4,16}$ Of them, b-HCAs are known to trigger a potent mitogenic signaling pathway that is prominent in $\mathrm{HCC}^{25}$ The incidence of HCC or borderline malignant tumors in b-HCAs has been reported to be up to $46 \%$, but such a malignant progression was seldom seen in other subtypes. ${ }^{26}$ HCA shows a higher risk of malignant transformation in men. ${ }^{27}$ Hepatitis, underlying glycogen storage disease, or sex steroid hormone abuse are predisposed to 
HCC. $^{28}$ On the contrary, it is known that H-HCA practically never degenerates into $\mathrm{HCC}$, although some very rare cases have been reported. ${ }^{29}$ The low risk of H-HCA degeneration may help to simplify the management of HCAs. Future studies should determine whether different subtypes of HCA carry different profiles of risk for bleeding, tumor recurrence and malignant transformation.

The present study has limits of note. First, this is a retrospective, single-center study with a small number of patients. Thus, multi-center studies are necessary to collect more data on rarely diagnosed cases. Second, the follow-up period was not sufficiently long to reliably evaluate the lifelong risk of tumor recurrence and malignant transformation.

In conclusion, surgery may be indicated if imaging studies show diagnostic ambiguity with HCC, growing tumor, or symptomatic mass with or without bleeding. Because of the risk of tumor recurrence and malignant transformation, long-term follow-up is necessary.

\section{CONFLICT OF INTEREST}

None of the authors have any conflicts of interest.

\section{ORCID}

Sung-Min Kim: https://orcid.org/0000-0003-2079-6141

Shin Hwang: https://orcid.org/0000-0002-9045-2531

Chul-Soo Ahn: https://orcid.org/0000-0002-3844-3646

Ki-Hun Kim: https://orcid.org/0000-0002-4016-0995

Deok-Bog Moon: https://orcid.org/0000-0002-8209-3540

Tae-Yong Ha: https://orcid.org/0000-0001-9932-0212

Gi-Won Song: https://orcid.org/0000-0002-4235-0434

Dong-Hwan Jung: https://orcid.org/0000-0001-5984-023X

Gil-Chun Park: https://orcid.org/0000-0003-1631-3258

Seung-Mo Hong: https://orcid.org/0000-0002-8888-6007

\section{AUTHOR CONTRIBUTIONS}

Conceptualization: SH. Data curation: CSA, KHK, DBM, TYH, GWS, DHJ, GCP. Methodology: SMH. Visualization: SH. Writing - original draft: SMK, SH. Writing - review \& editing: $\mathrm{SH}$.

\section{REFERENCES}

1. Rooks JB, Ory HW, Ishak KG, Strauss LT, Greenspan JR, Hill AP, et al. Epidemiology of hepatocellular adenoma. The role of oral contraceptive use. JAMA 1979;242:644-648.

2. Sasaki M, Yoneda N, Kitamura S, Sato Y, Nakanuma Y. Characterization of hepatocellular adenoma based on the phenotypic classification: the Kanazawa experience. Hepatol Res 2011; 41:982-988.

3. Chang CY, Hernandez-Prera JC, Roayaie S, Schwartz M, Thung SN. Changing epidemiology of hepatocellular adenoma in the United States: review of the literature. Int J Hepatol 2013;2013: e604860.

4. Zucman-Rossi J, Jeannot E, Nhieu JT, Scoazec JY, Guettier C, Rebouissou S, et al. Genotype-phenotype correlation in hepatocellular adenoma: new classification and relationship with HCC. Hepatology 2006;43:515-524.

5. Micchelli ST, Vivekanandan P, Boitnott JK, Pawlik TM, Choti MA, Torbenson M. Malignant transformation of hepatic adenomas. Mod Pathol 2008;21:491-497.

6. Chen YW, Jeng YM, Yeh SH, Chen PJ. P53 gene and Wnt signaling in benign neoplasms: beta-catenin mutations in hepatic adenoma but not in focal nodular hyperplasia. Hepatology 2002; 36(4 Pt 1):927-935.

7. Takayasu H, Motoi T, Kanamori Y, Kitano Y, Nakanishi H, Tange $\mathrm{T}$, et al. Two case reports of childhood liver cell adenomas harboring beta-catenin abnormalities. Hum Pathol 2002; 33:852-855.

8. Torbenson M, Lee JH, Choti M, Gage W, Abraham SC, Montgomery E, et al. Hepatic adenomas: analysis of sex steroid receptor status and the Wnt signaling pathway. Mod Pathol 2002; 15:189-196.

9. Belghiti J, Cauchy F, Paradis V, Vilgrain V. Diagnosis and management of solid benign liver lesions. Nat Rev Gastroenterol Hepatol 2014;11:737-749.

10. Zech CJ, Grazioli L, Breuer J, Reiser MF, Schoenberg SO. Diagnostic performance and description of morphological features of focal nodular hyperplasia in Gd-EOB-DTPA-enhanced liver magnetic resonance imaging: results of a multicenter trial. Invest Radiol 2008;43:504-511.

11. van den Esschert JW, van Gulik TM, Phoa SS. Imaging modalities for focal nodular hyperplasia and hepatocellular adenoma. Dig Surg 2010;27:46-55.

12. Bieze M, van den Esschert JW, Nio CY, Verheij J, Reitsma JB, Terpstra V, et al. Diagnostic accuracy of MRI in differentiating hepatocellular adenoma from focal nodular hyperplasia: prospective study of the additional value of gadoxetate disodium. AJR Am J Roentgenol 2012;199:26-34.

13. Bioulac-Sage P, Balabaud C, Bedossa P, Scoazec JY, Chiche L, Dhillon AP, et al. Pathological diagnosis of liver cell adenoma and focal nodular hyperplasia: Bordeaux update. J Hepatol 2007; 46:521-527.

14. Hwang S, Ha TY, Song GW, Jung DH, Ahn CS, Moon DB, et al. Quantified risk assessment for major hepatectomy via the indocyanine green clearance rate and liver volumetry combined with standard liver volume. J Gastrointest Surg 2015;19:1305-1314.

15. Hwang S, Lee YJ, Kim KH, Ahn CS, Moon DB, Ha TY, et al. The impact of tumor size on long-term survival outcomes after resection of solitary hepatocellular carcinoma: single-institution experience with 2558 patients. J Gastrointest Surg 2015; 19:1281-1290.

16. Margolskee E, Bao F, de Gonzalez AK, Moreira RK, Lagana $\mathrm{S}$, Sireci AN, et al. Hepatocellular adenoma classification: a 
comparative evaluation of immunohistochemistry and targeted mutational analysis. Diagn Pathol 2016;11:27.

17. Lin H, van den Esschert J, Liu C, van Gulik TM. Systematic review of hepatocellular adenoma in China and other regions. J Gastroenterol Hepatol 2011;26:28-35.

18. van Aalten SM, Thomeer MG, Terkivatan T, Dwarkasing RS, Verheij J, de Man RA, et al. Hepatocellular adenomas: correlation of MR imaging findings with pathologic subtype classification. Radiology 2011;261:172-181.

19. Cho SW, Marsh JW, Steel J, Holloway SE, Heckman JT, Ochoa ER, et al. Surgical management of hepatocellular adenoma: take it or leave it? Ann Surg Oncol 2008;15:2795-2803.

20. de'Angelis N, Memeo R, Calderaro J, Felli E, Salloum C, Compagnon $\mathrm{P}$, et al. Open and laparoscopic resection of hepatocellular adenoma: trends over 23 years at a specialist hepatobiliary unit. HPB (Oxford) 2014;16:783-788.

21. Vennarecci G, Santoro R, Antonini M, Ceribelli C, Laurenzi A, Moroni E, et al. Liver transplantation for recurrent hepatic adenoma. World J Hepatol 2013;5:145-148.

22. van Vledder MG, van Aalten SM, Terkivatan T, de Man RA, Leertouwer T, Ijzermans JN. Safety and efficacy of radiofrequency ablation for hepatocellular adenoma. J Vasc Interv Radiol 2011;22:787-793.

23. van Aalten SM, Terkivatan T, de Man RA, van der Windt DJ, Kok NF, Dwarkasing R, et al. Diagnosis and treatment of hepatocellular adenoma in the Netherlands: similarities and differences.
Dig Surg 2010;27:61-67.

24. Karkar AM, Tang LH, Kashikar ND, Gonen M, Solomon SB, Dematteo RP, et al. Management of hepatocellular adenoma: comparison of resection, embolization and observation. HPB (Oxford) 2013;15:235-243.

25. Pilati C, Letouzé E, Nault JC, Imbeaud S, Boulai A, Calderaro $\mathrm{J}$, et al. Genomic profiling of hepatocellular adenomas reveals recurrent FRK-activating mutations and the mechanisms of malignant transformation. Cancer Cell 2014;25:428-441.

26. Zucman-Rossi J, Benhamouche S, Godard C, Boyault S, Grimber G, Balabaud C, et al. Differential effects of inactivated Axin1 and activated beta-catenin mutations in human hepatocellular carcinomas. Oncogene 2007;26:774-780.

27. Farges O, Ferreira N, Dokmak S, Belghiti J, Bedossa P, Paradis $\mathrm{V}$. Changing trends in malignant transformation of hepatocellular adenoma. Gut 2011;60:85-89.

28. Yoneda N, Matsui O, Kitao A, Kozaka K, Gabata T, Sasaki M, et al. Beta-catenin-activated hepatocellular adenoma showing hyperintensity on hepatobiliary-phase gadoxetic-enhanced magnetic resonance imaging and overexpression of OATP8. Jpn J Radiol 2012;30:777-782.

29. Stueck AE, Qu Z, Huang MA, Campreciós G, Ferrell LD, Thung $\mathrm{SN}$. Hepatocellular carcinoma arising in an HNF-1 $\alpha$-mutated adenoma in a 23-year-old woman with maturity-onset diabetes of the young: a case report. Semin Liver Dis 2015;35:444-449. 